\title{
PERANAN DAN PEMANFAATAN MIKROALGA Tetraselmis chuii SEBAGAI BIOETANOL
}

\author{
Bertoka Fajar SP Negara, Nining Nursalim, Nurlaila Ervina Herliany, \\ Person Pesona Renta, Dewi Purnama, Maya Angraini Fajar Utami \\ Program Studi IImu Kelautan, Fakultas Pertanian, Universitas Bengkulu, \\ Bengkulu, Indonesia \\ E-mail:bfsp_negara@yahoo.com
}

Received July 2019, Accepted September 2019

\begin{abstract}
ABSTRAK
Bahan bakar fosil merupakan bahan bakar yang berasal dari pelapukan sisa mahluk hidup. Bahan bakar fosil bersifat tidak terbaharukan, maka pencarian bahan bakar alternatif yang terbarukan perlu dilakukan salah satunya bioetanol. Tetraselmis chuii dapat dijadikan bahan baku pembuatan bioetanol. Tujuan dari penelitian ini adalah untuk mengetahui volume bioetanol yang dihasilkan dari Fermentasi Tetraselmis chuii. Kultur Tetraselmis chuii selama 6 hari. Hidrolisis dilakukan dengan menambahkan $\mathrm{H}_{2} \mathrm{SO}_{4} \quad 0,2 \mathrm{M}$ pada suhu $121^{\circ} \mathrm{C}$ dengan tekanan $1 \mathrm{~atm}$ selama 30 menit, Fermentasi dengan Saccharomyces cereviseae selama 5 hari. Penelitian ini menghasilkan gula reduksi Tetraselmis chuii dengan kadar gula 4\% dan hasil fermentasi Tetraselmis chuii menghasilkan $12 \mathrm{ml}$ etanol dengan konsentrasi $1 \%$.
\end{abstract}

Kata Kunci : Tetraselmis chuii, Fermentasi, Hidrolisis, Bioetanol, Etanol

\section{ABSTRACT}

THE ROLE AND UTILIZATION OF MICROALGAE Tetraselmis chuii AS BIOETHANOL. Fossil fuels are the fuel produced from the weathering of living things. Fossil fuels are non-renewable, therefore the research of renewable energy is needed. Bioethanol could be good solution. Tetraselmis chuii can be used as the raw material for bioethanol. The purpose of this study was to determine the volume of ethanol through fermentation of Tetraselmis chuii. Tetraselmis chuii was cultured for 6 days. The hydrolysis used $0.2 \mathrm{M} \mathrm{H}_{2} \mathrm{SO}_{4}$ at $121^{\circ} \mathrm{C}$ and pressure of $1 \mathrm{~atm}$ for 30 minutes, and the fermentation used Sacscharomyces cereviseae for 5 days. The results showed that Tetraselmis chuii produced 4\% sugar and The fermentation produced 1\% bioethanol with volume was $12 \mathrm{ml}$.

Keywords : Tetraselmis chuii, Fermentation, Hydrolysis, Bioethanol, Ethanol 


\section{PENDAHULUAN}

Bahan bakar fosil adalah bahan bakar yang berasal dari pelapukan sisa makhluk hidup yang membentuk minyak bumi,batu bara dan gas alam. Bahan bakar fosil merupakan sumber energi yang tidak dapat diperbarui sehingga akan mengakibatkan menipisnya cadangan bahan bakar fosil di dalam bumi (Suhartoyo dan Rahmad, 2016). Upaya mengurangi konsumsi masyarakat terhadap Bahan Bakar Minyak (BBM) adalah dengan memanfaatkan energi alternatif terbarukan seperti yang tertuang dalam Peraturan Presiden (Perpres) Republik Indonesia Nomor 5 Tahun 2006 tentang Kebijakan Energi Nasional adalah melalui pengembangan energi terbarukan berbasis nabati atau sering disebut Bahan Bakar Nabati (BBN).

Biofuel yang sudah dikembangkan sebagai substitusi Bahan Bakar Nabati (BBN) saat ini adalah biodiesel dan bioetanol. Bioetanol adalah bahan bakar substitusi bensin (gasolin) yang berasal dari pengolahan (hidrolisis dan fermentasi) glukosa atau karbohidrat (Rahaju, 2013). Bioetanol di Indonesia masih memanfaatkan komoditi pangan seperti ubi kayu dan molase tebu sebagai bahan baku. Pemanfaatan bahan non pangan untuk bahan baku pembuatan bioetanol sangat perlu (Aiman, 2014). Bahan non pangan yang dapat dimanfaatkan sebagai bioetanol salah satunya mikroalga.

Mikroalga mengandung bahan-bahan penting yang sangat bermanfaat, misalnya protein, karbohidrat, lemak dan asam nukleat sehingga bisa dijadikan sebagai sumber bioenergi. Mikroalga mempunyai prospek yang sangat baik untuk dikembangkan sebagai salah satu bahan baku penghasil biofuel. Beberapa biofuel yang dapat dihasilkan dari mikroalga yaitu biohidrogen, biodiesel, bioetanol, dan biogas (Miranda dkk., 2014).

Tetraselmis chuii merupakan alga bersel tunggal, mempunyai empat buah flagel berwarna hijau (green flagella). Tetraselmis chuii digunakan sebagai bahan baku pembuatan bioetaniol karena mudah dikembangbiakan, tidak membutuhkan lahan yang luas dan tidak bersinggungan dengan bahan pangan. Azzahra dkk. (2015) ; Miranda dkk. (2014) dan Quaishum dkk. (2015) telah memanfaatkan Tetraselmis chuii sebagai bahan baku pembuatan bioetanol. Beberapa penelitian sebelumya tidak melakukan proses fermentasi untuk menghasilkan bioetanol, sehingga penelitian ini dilakukan untuk memperoleh bioetanol dari Tetraselmis chuii melalui proses fermentasi. Tujuan dari penelitian adalah untuk memperoleh volume bioetanol yang dihasilkan dari fermentasi Tetraselmis chuii. Penelitian ini diharapkan dapat bermanfaat sebagai ilmu pengetahuan dan pengembangan energi alternatif. 


\section{MATERI DAN METODE}

\section{Materi Penelitian}

Materi penelitian yang digunakan adalah mikroalga jenis Tetraselmis chuii yang berasal dari (BBPBL) Balai Besar Perikanan Budidaya Laut Lampung.

\section{Kultur Tetraselmis chuii}

Kultur Tetraselmis chuii diawali dengan menyiapkan air laut salinitas 28 ppt dilanjutkan dengan seterilisasi air laut dan pencucian wadah kultur. Seterilisasi air dilakukan dengan menyaring air laut dan menambahkan iodine $10 \%$ dan diberi aerasi selama 30 menit.

Kultur Tetraselmis chuii mengunakan 3 toples sebagai wadah kultur. Kultur dilakukan dengan jumlah $5.000 \mathrm{~mL}$ dengan kepadatan $300.000 \mathrm{sel} / \mathrm{mL}$ (Putri dkk., 2013) dan pupuk conwy ditambahkan sebagai nutrien sebanyak $1 \mathrm{~mL} / 1 \mathrm{~L}$ air laut steril (Rizky $d k k ., 2012)$.

\section{Pengamatan Kepadatan Sel Tetraselmis chuii}

Pengamatan dilakukan 1 kali tiap 24 jam, dengan 2 kali ulangan mengunakan hemocytometer. Sampel sebanyak 0,1-0,5 mL dimasukkan kdalam hemocytometer diamati dibawah mikroskop Menghitung sampel dengan menghitung jumlah sel yang berada pada kotak. Berdasarkan Rizky dkk. (2012) kepadatan sel dihitung dengan mengunakan rumus :

$$
\text { Jumlah } \frac{\text { sel }}{\mathrm{ml}}=\frac{\mathrm{A}+\mathrm{B}+\mathrm{C}+\mathrm{D}+\mathrm{E}}{5} \times 25 \times 10^{4}
$$

Keterangan:
$A, B, C, D, E$ : Jumlah sel yang dihitung menggunakan Haemocytometer tiap kamar
$5 \quad:$ Jumlah kotak yang diamati dalam kamar
$25 \quad:$ Jumlah seleru kotak

\section{Pembuatan Pasta dan Powder Tetraselmis chuii}

Pembuatan pasta Tetraselmis chuii dilakukan saat kultur mencapai puncak populasi. Pembuatan pasta menggunakan $\mathrm{NaOH}$ dengan konsentrasi 125 ppm. Pembuatan pasta dimulai dengan memasukkan $\mathrm{NaOH}$ ke dalam wadah dan melarutkannnya dengan air, dan dilakukan pengadukan selama menuangkan larutan $\mathrm{NaOH}$ untuk meratakan $\mathrm{NaOH}$.

Tetraselmis chuii yang sudah diberi $\mathrm{NaOH}$ diamkan selama 24 jam. Tetraselmis chuii yang mengendap dipisahkan antara air dan endapan, kemudian di masukan air tawar dan tunggu 3 jam hingga terjadi pemisahan antara air dan endapan. Endapan disaring dengan 
mengunakan kain satin dan didiamkan selama 24 jam. Endapan dianginanginkan hingga kering.

\section{Hidrolisis}

Powder Tetraselmis chuii dicampurkan dengan larutan $\mathrm{H}_{2} \mathrm{SO}_{4} 0,2 \mathrm{M}$ dengan perbandingan 1:20 (w/v). Campuran powder Tetraselmis chuii dan $\mathrm{H}_{2} \mathrm{SO}_{4}$ dihidrolisis pada suhu $120^{\circ} \mathrm{C}$. Selanjutnya dilakukan penetralan menggunakan $\mathrm{NaOH}$ hingga $\mathrm{pH}$ 6. Hasil hidrolisis diukur kadar gula reduksinya (Negara, 2014).

\section{Fermentasi}

Hasil hidrolisis sebanyak $60 \mathrm{~mL}$ dimasukan kedalam erlemeyer $250 \mathrm{~mL}$ dan ditambahkan Saccharomyces cereviseae sebanyak 1\% (w/v), urea $1 \%(\mathrm{w} / \mathrm{v})$ dan NPK 1\% (w/v). Fermentasi dilakukan selama 5 hari pada suhu $30^{\circ} \mathrm{C}$ (Jaya $\left.d k k ., 2018\right)$.

\section{Destilasi}

Hasil fermentasi didestilasi pada suhu $78^{\circ} \mathrm{C}$, selama 1 jam (Muin $d k k$, 2014) untuk mendapatkan etanol. Etanol yg diperoleh dihitung jumlahnya $(\mathrm{mL})$ dan diukuran kadarnya dengan mengunakan alkoholmeter.

\section{HASIL DAN PEMBAHASAN}

\section{Kultur Tetraselmis chuii}

Tetraselmis chuii merupakan alga hijau yang memiliki sifat uniseluler dengan bentuk oval sampai berbentuk elips. Tetraselmis chuii melakukan fotosintesis dalam memenuhi kebutuhan hidupnya. Menurut Hamandes et al. (2015) dinding sel Tetraselmis chuii mengandung selulosa dan hemiselulosa. Mikroalga mengalami beberapa fase dalam hidupnya. Fase hidup secara normal meliputi fase adaptasi (pertumbuhan tidak terlihat jelas), fase eksponensial atau pertumbuhan (jumlah sel meningkat secara drastis), fase stasioner (kepadatan sel relatif tidak berubah) dan fase drop atau kematian (kepadatan sel berkurang) (Ru'yatin, 2015).

Berdasarkan hasil kultur, Tetraselmis chuii mengalami 4 fase yaitu fase adaptasi, fase pertumbuhan, fase stasioner dan fase kematian. Kepadatan sel Tetraselmis chuii mengalami peningkatan sejak hari pertama kultur, setelah terjadi puncak kepadatan sel, maka terjadi penurunan jumlah sel. Fase adaptasi terjadi pada hari ke 0 sampai dengan hari ke 1 , fase pertumbuhan terjadi pada hari ke 1 sampai dengan hari ke 3, fase stasioner terjadi pada hari ke 4 dan merupakan puncak dari kepadatan dengan jumlah individu sebanyak $910.000 \mathrm{sel} / \mathrm{mL}$ dan fase kematian mulai terjadi pada hari ke 5 hingga kultur selesai (Gambar 1). 
Hasil penelitian ini sejalan dengan penelitian yang dilakukan oleh Putri dkk. (2013) dengan mengunakan Tetraselmis sp. namun pada penelitian ini mengalami fase pertumbuhan yang lebih lama. Fase pertumbuhan pada penelitian Putri $d k k$. (2013) terjadi hanya 1 hari yaitu pada hari ke 2, pada hari ke tiga sudah puncak kepadatan. Hal ini diduga dikarenakan nutrien yang berbeda.

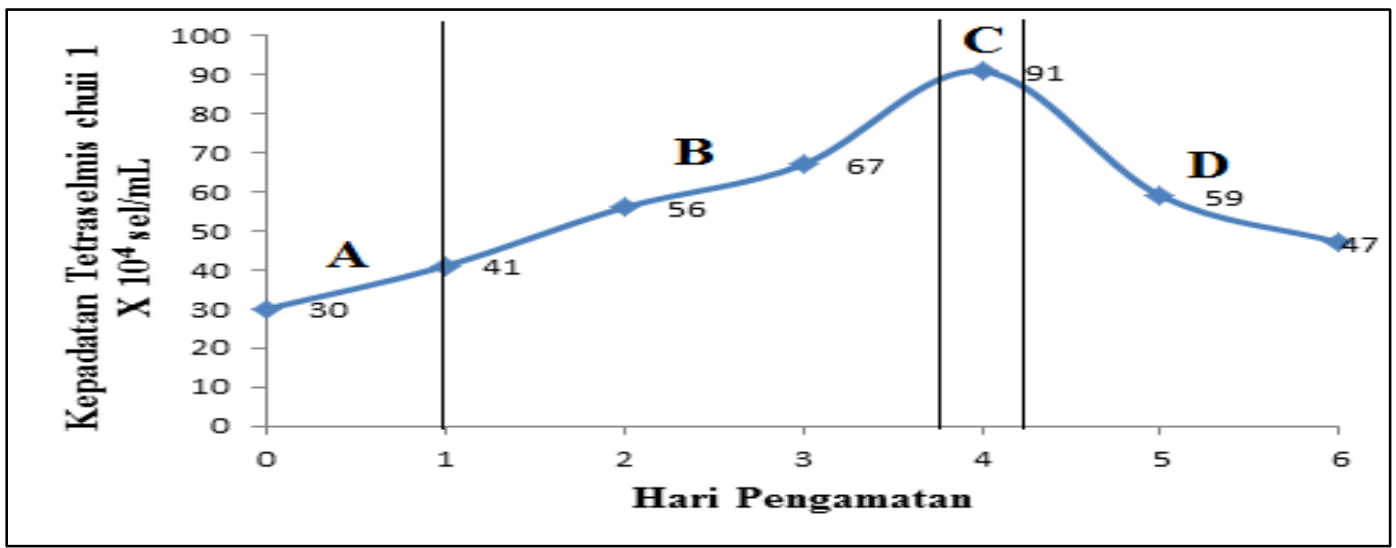

Gambar 1. Kepadatan Tetraselmis chuii A (fase adaptasi), B (fase pertumbuhan), C (fase stasioner) dan D (fase kematian).

Kultur dilakukan dengan kepadatan awal $30 \times 10^{4} \mathrm{sel} / \mathrm{mL}$. Fase adaptasi terjadi sesaat setelah kultur dilakukan sampai dengan hari pertama. Terlihat dari belum terjadi peningkatan yang signifikan. Fase adaptasi dipengaruhi oleh jenis dan umur sel mikroorganisme, Tetraselmis mengalami masa adaptasi berkisar 1 sampai 3 hari (Ru'yatin dkk., 2015). Menurut Ru'yatin $d k k$., (2015) fase adaptasi dipengaruhi oleh ketersediaan nutrien, semakin sedikit nutrien semakin lama pase adaptasi karena Tetraselmis chuii harus menyesuaikan dengan nutrien yang ada.

Fase pertumbuhan merupakan fase yang penting dimana terjadi peningkatan sel menjadi beberapa kali lipat. Peningatan jumlah sel secara signifikan disebabkan karena kandungan unsur hara (nutrien) yang tersedia masih banyak dalam media kultur sehingga memungkinkan Teraselmis chuii melakukan pembelahan sel secara berulang-ulang Putri dkk. (2013) dan Matakupan (2009).

Fase stasioner merupakan fase dimana terjadinya puncak kepadatan. Pada puncak kepadatan, jumlah sel relatif sama antara kematian dan pertumbuhan. Hal ini disebabkan sel telah mencapai titik jenuh.

Fase kematian terjadi setelah puncak kepadatan, terjadi penurunan kepadatan secara signifikan dari kepadatan $91 \times 10^{4}$ sel $/ \mathrm{mL}$ menjadi $59 \mathrm{X}$ $10^{4} \mathrm{sel} / \mathrm{mL}$. Penurunan dan kematian mikroalga terjadi diduga disebabkan oleh kapasitas daya dukung media yang telah melampaui batas (terlalu padat) dan penggunaan nutrien dari medium oleh sel telah mencapai batas maksimum sehingga terjadi penghambatan proses metabolisme (Amanantin dan Hurhidayati, 2013). 
Nutrien menjadi salah satu faktor pendukung kepadatan Tetraselmis chuii. Komposisi nutrien yang lengkap dan konsentrasi nutrien yang tepat menentukan produksi biomassa dan kandungan gizi mikroalga (Amanatin dan Nurhidayati, 2013). Conwy adalah pupuk yang umum digunakan pada kultur mikroalga tanpa terkecuali Tetraselmis chuii. Pupuk Conwy juga telah digunakan untuk kultur mikroalga seperti yang telah dilakukan Dayanto dkk. (2013) untuk Nannochloropsis sp : Amanatin dan Nurhidayati (2013) untuk Spirulina sp. Nutrien yang dibutuhkan Tetraselmis chuii dalam jumlah sedikit yaitu Mangan, Seng, Boron, Molibdenum, dan Cobalt.

Panen dilakukan pada saat di puncak kepadatan atau pada saat fase stasioner. Fase stasioner merupakan fase dimana kepadatan paling tinggi, sehingga pemanenan pada fase ini diharapkan didapat biomasa terbanyak selama kultur dilakukan. Pada penelitian ini dilakukan panen pada hari ke 4 dengan mengunakan teknik flokulan. Teknik atau metode yang dapat digunakan untuk panen mikroalga laut adalah sentrifugasi, filtrasi dan flokulasi (Kawaroe et al., 2016). Hasil panen diperoleh 8 gram pasta. Dari 8 gram pasta dikeringkan, didapat 3 gram powder dengan kadar air $13,12 \%$.

\section{Kadar Gula Reduksi}

Hidrolisis adalah proses pemecahan karbohidrat menjadi gula-gula sederhana. Proses hidrolisis yang dilakukan pada bahan-bahan yang mengandung karbohidrat menghasilkan senyawa gula sederhana, seperti glukosa dan xilosa. Hidrolisis dapat dilakukan dengan mengunakan asam dan enzim. Proses hidrolisis mengunakan asam dapat menggunakan $\mathrm{H}_{2} \mathrm{SO}_{4}$ seperti yang dilakukan oleh $\mathrm{Ho}$ et al. (2013) ; Ashokkumar et al. (2015) dan Miranda et al. (2012), dapat juga menggunakan $\mathrm{HNO}_{3}, \mathrm{NAOH}$, dan HCL yang telah dilakukan oleh Markau et al. (2013), Miranda et al. (2012), dan Zhou (2012). Hidrolisis menggunakan enzin selulase telah dilakukan oleh Azzahra dkk. (2015). Proses hidrolisis pada penelitian ini mengunakan asam. Proses hidrolisis memiliki pengaruh besar terhadap kadar gula yang dihasilkan dan hidrolisis dipengaruhi oleh beberapa faktor antara lain konsentasi asam, waktu, suhu, jumlah bahan baku, dan kadar karbohidrat.

Hasil dari proses hidrolisis Tetraselmis chuii menggunakan $\mathrm{H}_{2} \mathrm{SO}_{4}$ $0,2 \mathrm{M}$, suhu $121^{\circ} \mathrm{C}$ pada tekanan 1 atm selama 30 menit didapat hasil kadar gula 4\%. Sedangkan penelitian Miranda dkk. (2014) melakukan hidrolisis mengunakan $\mathrm{H}_{2} \mathrm{SO}_{4}$ dengan konsentasi $0.25 ; 0.75 ; 1,25$ dan $1.75 \%$ dengan gula hasil hidrolisis terbaik pada konsentasi $1.75 \%$ yaitu $1,815 \%$. Semakin tinggi konsentrasi $\mathrm{H}_{2} \mathrm{SO}_{4}$ akan memberikan kesempatan yang lebih bagi selulosa dan hemiselulosa untuk dihidrolisis menjadi gula sederhana (Sukowati dkk., 2014).

Lama proses hidrolisis yang dilakukan mempengaruhi kadar gula hasil hidrolisis. Quaishum dkk. (2015) melakukan penelitian dengan perbedaaan waktu hidrolisis selama 10 menit, 30 menit dan 50 menit mengunakan $\mathrm{H}_{2} \mathrm{SO}_{4} 1 \%$, didapatkan waktu hidrolisis paling baik pada 
waktu 30 menit, dengan menghasilkan gula 7,27\%. Penelitian Ho et al. (2013) mengunakan Chlorella vulgaris dengan lama 120 menit menghasilkan $0,472 \%$. Semakin lama waktu hidrolisis maka semakin lama kesempatan $\mathrm{H}_{2} \mathrm{SO}_{4}$ untuk memecah gula komplek menjadi gula sederhana, namun setiap jenis dari mikroalga memiliki waktu optimal. Jika proses hidrolisis melebihi waktu optimum maka kadar gula akan menurun. Diduga hal ini terjadi dikarenakan ion $\mathrm{H}^{+}$pada asam telah mencapai titik optimumnya dalam melepas ikatan rantai glikosidik pada selulosa (Quaishum dkk., 2015).

Suhu pada proses hidrolisis dapat menpercepat pemecahan gula komplex menjadi gula sederhana. Miranda $d k k$. (2014) melakukan proses hidrolisis dengan suhu $60^{\circ} \mathrm{C}$ dan $70^{\circ} \mathrm{C}$, dari ke 2 vasiasi suhu tersebut yang menghasilkan kadar gula lebih tinggi pada suhu $70^{\circ} \mathrm{C}$ dengan kadar gula hasil hidrolisis sebesar 1,815\%. Quaishum dkk., (2015) melakukan hidrolisis dengan suhu $100^{\circ} \mathrm{C}$ menghasilkan gula $7,27 \%$. Semakin tinggi suhu yang digunakan pada proses hidrolisis menghasilkan kadar gula lebih tinggi. Hal ini diduga disebabkan suhu mempengaruhi reaksi asam memecah gula.

Meningkatnya biomassa pada proses hidrolisis berpengaruh terhadap gula yang dihasilkan. Bahan baku yang digunakan pada penelitian ini mengunakan powder Tetraselmis chuii sebanyak 3 gram menghasilkan gula 4\%. Sedangkan penelitian Quaishum dkk., (2015) mengunakan powder Tetraselmis chuii sebanyak 3,5 gram dihasilkan gula yang bebeda yaitu dan $7,27 \%$. Semakin banyak bahan baku yang digunakan, semakin banyak gula komplek yang dipecah menjadi gula sederhana dan semakin tinggi kadar gula yang dihasilkan.

Karbohidrat pada mikroalga dapat berupa selulosa dan pati dan terletak di dalam dan luar bagian sel. Menurut Sani dkk. (2014) kandungan karbohidrat Tetraselmis chuii sebesar $12,10 \%$. Penelitian mengunakan Tetraselmis telah dilakukan oleh Azzahra dkk. (2015) dan Quaishum dkk. (2015) dengan hasil hidrolisis 0,28\% dan 7,27\%. Beberapa peneliti memanfaatkan karbohidrat mikroalga telah dilakukan oleh $\mathrm{Ho}$ et al. (2013) dan Mendez et al. (2014) menggunakan Chlorella vulgaris dengan kandungan karbohidrat 12 - 17\% (Sugaya et al., 2016) menghasilkan gula $0,09 \%, 0,472 \%$ dan $0,25 \%$. Jaya dkk. (2018) mengunakan Spirogyra sp. yang memiliki kandungan karbohidrat sebesar $33-46 \%$ dihasilkan gula $17 \%$. Semakin tinggi kandungan karbohidrat, semakin besar kemungkinan gula sederhana yang terbentuk.

Kandungan karbohidrat sama, dapat menghasilkan kadar gula yang berbeda. Pada penelitian ini ; penelitian Azzahra dkk. (2015) dan penelitian Quaishum dkk. (2015) mengunakan bahan baku Tetraselmis chuii. Ketiga penelitian menghasilkan gula berturut-turut 4\%, 0,28\% dan 7,27\%. Dari ke 3 penelitian, penelitian Azzahra dkk. (2015) memiliki hasil yang paling rendah dan Quaishum dkk. (2015) memiliki hasil yang paling tinggi. Perbedaan kadar gula diduga dikarenakan proses hidrolisis yang digunakan, seperti perbedaan suhu, lama waktu proses hidrolisis dan penggunaan asam ataupun enzim. 


\section{Bioetanol}

Bioetanol dihasilkan dari proses fermentasi. Fermentasi merupakan pengubahan gula menjadi bioetanol dengan bantuan mikroorganisme. Mikroorganisme yang dapat digunakan pada saat melakukan fermentasi adalah bakteri (Zymomonas mobilis dan Eschericia coli) dan kapang (Saccharomyces cerevisiae). Saccharomyces cerevisiae dapat merubah gula (Assadad dkk., 2010).

Penelitian ini mengunakan kamir (Saccharomyces cereviseae) sebagai mikroorganisme yang mengubah gula menjadi bioetanol. Saccharomyces cereviseae adalah jamur yang terdiri dari satu sel, dan tidak membentuk hifa, Saccharomyces cereviseae termasuk golongan jamur Ascomycotin dan bereproduksi dengan membentuk tunas (Bahri $d k k$., 2018). Saccharomyces cereviseae melakukan proses glikolisis sehingga dapat mengubah gula menjadi bioetanol (Handayani dkk, 2016)

Saccharomyces cereviseae menyukai kondisi aerobik untuk membentuk sel dan produk. Saccharomyces cereviseae akan melakukan respirasi sel serta mengubah susbtrat gula yang tersedia menjadi $\mathrm{CO}_{2}$ dan $\mathrm{H}_{2} \mathrm{O}$ dengan membentuk sel dalam keadaan aerobik. Ketika sudah membentuk sel pada waktu tertentu, maka Saccharomyces cereviseae akan melakukan proses fermentasi secara maksimal. Proses fermentasi dilakukan dengan cara mengkonversi gula yang tersedia menjadi bioetanol dan karbondioksida.

Fermentasi Tetraselmis chuii menghasilkan $1 \%$ bioetanol sebanyak $11 \mathrm{~mL}$. Produksi bioetanol dipengaruhi oleh jumlah gula reduksi yang dihasilkan, pertumbuhan Saccharomyces cereviseae, serta kondisi lingkungan pada proses fermentasi.

Semakin tinggi gula reduksi maka semakin tinggi kadar bioetanol terbentuk. Konsentrasi gula yang optimum untuk fermentasi bioetanol adalah $10-18 \%$. Konsentrasi gula terlalu tinggi dapat menghambat kerja ragi. Pembentukan bioetanol terhambat apabila kadar bioetanol mencapai $13-15 \%$, karena ragi tidak tahan terhadap kadar bioetanol dan sel ragi akan mati. Kadar gula reduksi pada penelitian Sarfat $d k k$. (2013) adalah $5,26 \%$ menghasilkan bioetanol sebesar 2,38\%. Kadar bioetanol hasil penelitian ini lebih rendah dari pada hasil penelitian Sarfat $d k k$. (2013).

Kadar pada penelitian Jaya dkk. (2018) dengan menggunakan Spirogyra sp. yang memiliki gula $17 \%$ menghasilkan kadar bioetanol $3,87 \%$. Kim et al. (2014) menggunakan bahan baku Chlorella vulgaris dengan kadar gula hasil hidrolisis $0,60 \%$, dihasilkan bioetanol sebesar $0,070 \%$. Perbedaan bioetanol yang dihasilkan karena perbedaan kadar gula. Gula menjadi substrat Saccharomyces cereviseae. Pada penelitian ini aktifitas Saccharomyces cereviseae dalam mengubah gula lebih efektif, karena dari $4 \%$ gula dihasilkan $1 \%$ bioetanol.

Saccharomyces cereviseae mengkonversi gula menjadi bioetanol pada kondisi kadar karbohidrat tinggi dan kadar oksigen terbatas. Reaksi pembentukan bioetanol dari glukosa dalam suasana anaerob yakni sebagai berikut:

$$
\mathrm{C}_{6} \mathrm{H}_{12} \mathrm{O}_{6} \rightarrow 2 \mathrm{C}_{2} \mathrm{H}_{5} \mathrm{OH}+2 \mathrm{CO}_{2}+\text { energi (Syaidah, 2018) }
$$


Penelitian ini dilakukan dengan mengunakan 1\% Saccharomyces cereviseae menghasilkan bioetanol 1\%. Sedangkan penelitian Ningrum dkk (2016), dengan bahan baku Spirogyra sp. mengunakan Saccharomyces cereviseae sebanyak $5 \%$ menghasilkan kadar bioetanol 7,53\%. Semakin tinggi jumlah Saccharomyces cereviseae yang digunakan maka semakin meningkatkan kadar bioetanol yang dihasilkan karena semakin banyak mikroorganisme yang mengubah gula menjadi bioetanol. Jenis kamir mempengaruhi kadar bioetanol yang dihasilkan. Ho et al., (2013) menggunakan Zymomonas mobilis menghasilkan bioetanol 0,178\%. Dibandingkan dengan hasil penelitian ini, penelitian ini lebih tinggi kadar bioetanol yang dihasilkan. Penggunaan Saccharomyces cereviseae lebih efektif mengubah gula sederhana menjadi bioetanol daripada Zymomonas mobilis.

Waktu fermentasi berpengaruh terhadap kadar bioetanol yang dihasilkan. Waktu fermentasi penelitian ini selama 5 hari dan menghasilkan kadar bioetanol 1\%. Ningrum dkk. (2016) melakukan fermentasi penelitian selama 10 hari dan dihasilkan bioetanol 7,53\%. Sedangkan penelitian yang dilakukan Sarfat $d k k$, (2013) dengan lama waktu fermentasi 6 hari terbentuk bioetanol 2,38\%. Semakin lama waktu fermentasi semakin tinggi kadar bioetanol yang terbentuk karna Saccharomyces cereviseae akan lebih banyak mengubah gula menjadi etanol.

Hasil penelitian ini mengindikasikan bahwa Tetraselmis chuii memiliki potensi untuk dijadikan sebagai bahan baku bioetanol, namun jika akan dimanfaatkan sebagai alternatif bahan bakar minyak perlu dilakukan penelitian lebih lanjut untuk mengoptimalkan proses hidrolisis dan fermentasi agar bioetanol yang dihasilkan lebih tinggi.

\section{KESIMPULAN}

Hidrolisis yang dilakukan menghasilkan kadar gula 4\%. Fermentasi menghasilkan $1 \%$ bioetaniol. Hal ini menunjukkan bahwa mikroalga jenis Tetraselmis chuii memiliki manfaat yang dapat dijadikan sebagai bahan baku bioetanol.

\section{DAFTAR PUSTAKA}

Aiman, S. 2014. Perkembangan Tehnologi dan Tantangan Dalam Riset Bioetanol di Indonesia. JKTI. 16(20):108-177.

Amananti, D. $R$ dan T. Nurhidayati. 2013. Pengaruh Kombinasi Konsentrasi Media Ekstrak Tauge (MET) dengan Pupuk Urea Terhadap Kadar Protein Spirulina sp. Jurnal Sains Dan Seni Pomits. 2(2):182-184. 
Ashokumar, V., Z. Salam., O.N. Tiwari., S. Cahinnasami., S. Mohammed dan F. N. Ani. 2015. An Integrated Approach for Biodiesel and Bioethanol Production from Scenedesmus bijugatus Cultivated in a Vertical Tubular Photobioreactor. Energy Conversion and Management. 101. 778-786.

Assadad, L., B. S. B. Utomo dan R. N. Sari. 2010. Pemanfaatan Mikroalga Sebagai Bahan Baku Bioetanol. Squalen. 5( 2):51-58.

Azzahra, N., A. Amri dan S. P. Utami. 2015. Hidrolisis Mikroalga Tetraselmis Chuii Menjadi Glukosa Menggunakan Enzim Selulase. Jom Fteknik. 2(1):1-4.

Bahri, S., A. Aji dan F. Yani. 2018. Pembuatan Bioetanol dari Kulit Pisang Kepok dengan Cara Fermentasi menggunakan Ragi Roti. Jurnal Teknologi Kimia. 7(2):85-100.

Dayanto, L. B. D., R. Diantari Dan S. Hudaida. 2013. Pemanfaatan Pupuk Cair Tnf® Untuk Budidaya Nannochloropsis sp. E-Jurnal Rekayasa Dan Teknologi Budidaya Perairan. 2(1):163-168.

Handayani, S. S., S. Hadi dan H. Patmala. 2016. Fermentasi Gula Hasil Hidrolisis Buah Kubi Untuk Bahan Baku Bioetanol. J. Pijer MIPA. 11(1):28-33.

Ho, S.H., S.W. Huang., C.Y Chen., T. Hasunuma., A. Kondo dan J.S Chang. 2013. Bioethanol Production Using Carbohydrate-rich Microalgae Biomass as Feedstock. Biore source Technology. 135. 191-198.

Jaya, D., R. Setiyaningtyas dan S. Prasetyo. 2018. Pembuatan Bioetanol Dari Alga Hijau Spirogyra sp. Eksergi. 15(1):16-19.

Kawaroe, M., T. Prartono., A. Sunutdin dan D. Saputra. 2016. Marine Microalgae Tetraselmis suecica as Flocculant Agent of Bioflocculation Method. HAYATI Journal of Biosciences. 30. 1-5.

Kim, K. H., I. S. Choi., H. M. Kim., S. G. Wi dan H. J. Bae. 2014.Bioethanol production from the nutrient stress-induced microalga Chlorella vulgaris by enzymatic hydrolysis and immobilized yeast fermentation. Bioresource Technology. 153. 47-54.

Markau, G., I. Angelidaki. E. Narantezis dan D. Deorgakakis. 2013. Bioethanol Production by Carbohydrate-Enriched Biomass of Arthrospira (Spirulina) platensis. Energies. 6. 3937- 3950.

Matakupan, J. 2009. Studi Kepadatan Tetraselmis Chuii Yang Dikultur Pada Intensitas Cahaya Yang Berbeda. Jurnal TRITON. 5(2):31-35. 
Mendez, L., A. Mahdy., M. Demuez., M. Ballesteros dan C. GonzálezFernández. 2014. Effect of High Pressure Thermal Pretreatment on Chlorella vulgaris Biomass: Organic Matter Solubilisation and Biochemical Methane Potential. Fuel. 117. 674-679.

Miranda, G., A. Amri, dan S. P. Utami. 2014. Hidrolisis Mikroalga Tetraselmis chuii Dengan Variasi Konsentrasi Asam Sulfat dan Temperatur. Jurnal Jom Ftehnik. 1(2):1-5.

Miranda, J. R., P. C. Passarinho dan L. Gouveia. 2012. Pre-treatment Optimization of Scenedesmus obliquus Microalga for Bioethanol Production. Bioresource Technology. 104. 342-348.

Negara, B. F. S. P. 2014. Aktivitas, Karakteristik, dan Aplikasi Enzim Agarase Dari Kapang Laut Untuk Hidrolisis Gelidium Sp. Sebagai Bahan Baku Bioetanol. Tesis. Sekolah Pascasarjana Institut Pertanian Bogor. Bogor.

Ningrum, A. S. W., V. Liani dan A. R. Widyasti. 2016. Pengaruh Variasi Asam Dalam Fermentasi Biomassa Berbahan Baku Alga Spirogyra Sp. Terhadap Kadar Etanol. PELITA. 11(2):21-32.

Purti, B., A. Vikary dan H. W. Maharani. 2013. Pemanfaatan Air Kelapa Sebagai Pengkaya Media Pertumbuhan Mikroalga Tetraselmis sp. Prosiding Semirata FMIPA Universitas Lampung, 2013. Jurusan Budidaya Perairan Fakultas Pertanian Universitas Lampung. Universitas Lampung. Bandar Lampung.

Quaishum, S., A. Amri dan S. P. Utami. 2015. Hidrolisis Mikroalga Tetraselmis chuii Menjadi Glukosa mengunakan $\mathrm{H}_{2} \mathrm{SO}_{4}$ dengan Variasi Hidrolisis. Jom Fteknik. 2(1):1-5.

Rahaju, R. S. N., M. Yani., S. H. Sucahyo dan D. A. Santosa. 2013. Seleksi dan Karakterisasi Ganggang Mikro Indigen Air Tawar Sebagai Penghasil Karbohidrat Untuk Energi Terbarukan. Limnotek. 20(2):178-190.

Rizky, Y. A., I. Raya, dan S. Dali. 2012. Penentuan Laju Pertumbuhan Sel Fitoplankton Chaetoceros calcitrans, Chlorella vulgaris, Dunaliella salina, dan Porphyridium cruentum. Penelitian. Fakultas MIPA. Universitas Hasanuddin Makassar.

Ru'yatin., I. S. Rohyani dan L. Ali. 2015. Pertumbuhan Tetraselmis dan Nannochloropsis Pada Skala Laboratorium. Pros Sem Nas Masy Biodiv Indon. 1(2):296-299. 
Sani, R. N., F. C. Nisa., R. D. Andriani dan J. N. Maligan. 2014. Analisis Rendemen dan Skrining Fitokimia Ekstrak Etanol Mikroalga Laut Tetraselmis Chuii. Jurnal Pangan dan Agroindustri. 2(2):121-126.

Sarfat, M. S., M. Rahayuningsih., A. Muryani dan D. Setianingsih. 2013. Modifikasi Fermentasi Hidrolisat Asam Eucheuma Cottonii Menjadi Bioetanol Menggunakan Saccharomyces Cerevisiae dan Pachysolen Tannophilus. Jurnal Teknologi Industri Pertanian. 23 (3):199-209.

Sugaya, T., Varman, M., Masjuki, H.H., Renganathan, S., 2016. Macroalgae and Microalgae as a Potential Source for Commercial Applications Along With Biofuels Production: a Biorefinery Approach. Renewable and Sustainanble Energy Reviews. 55. 909-941.

Suhartoyo dan Rahmad. 2016. Effektifitas Biobriket Limbah Biomass Sebagai Bahan Bakar Ramah Lingkungan Skala Rumah Tangga. Hal. 107-112. Pros iding SNATIF Ke -3 Tahun 2016, Universitas Muara Kudus. Yokyakarta. Indonesia.

Sukowati, A., Sutikno dan S. Rizal. 2014. Produksi Bioetanol Dari Kulit Pisang Melalui Hidrolisis Asam Sulfat. Jurnal Teknologi dan Industri Hasil Pertanian. 19(3):274-288.

Zhou, N., Y. Zhang., X. Gong., Q. Wang dan Y. Ma. 2012. lonic Liquidsbased Hydrolysis of Chlorella Biomass for Fermentable Sugars. Bioresource Technology. 118. 512-517. 